\title{
STOP 6: Morphology, internal structure and texture of inland dunes at the Smilškalni site, Middle Gauja Lowland
}

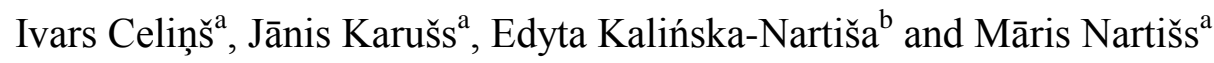 \\ ${ }^{\mathrm{a}}$ University of Latvia, Latvia \\ ${ }^{\mathrm{b}}$ University of Tartu, Estonia
}

\section{The geomorphological background of the site}

The Middle Gauja Lowland was formed by the Middle Gauja ice lobe of the Peipsijärv ice stream during the last, Weichselian glaciation (Zelčs and Markots 2004). Between the Gulbene (Middle Lithuania) and Linkuva (North Lithuania) deglaciation phases, dated to 15.5-14.5 ka (Kalm et al. 2011; Zelčs et al. 2011), the ice started to retreat and a large icedammed lake with a falling water level covered the lowland. An ice-dammed lake with a water level of $110 \mathrm{~m}$ a.s.l. covered most of the Middle Gauja Lowland. An abundance of glaciolacustrine sediments in some of the hypsometrically lower parts of the lowland indicates the presence of stagnant ice (Nartišs and Zelčs 2011). After the Linkuva reactivation of the Burtnieks lobe, ice continued to retreat and the Middle Gauja ice-dammed lake drained to the Smiltene ice-dammed lake and Strenči proglacial lake. During drainage, the water masses formed part of the valley of the River Gauja (Āboltinšs 1971; Nartišs and Zelčs 2011).

In most of the lowland a 10-20 m thick layer of Quaternary deposits covers the Upper Devonian bedrock. The lowermost part of the Quaternary sequence mainly consists of till. Across most of the lowland the till is overlain by glaciolacustrine fine-grained sand and silty sand in the central and southern part of the lowland, and by silty clay in the northern and north-eastern part (Juškevičs and Skrebels 2002). In some hypsometrically higher parts of the lowland varved clay up to $9 \mathrm{~m}$ thick can be found. In the whole of the Middle Gauja Lowland the topmost part of the glaciolacustrine sediments has been reworked by aeolian processes. However, dune landforms occur only in the southern and central part of the lowland. In other parts of this territory coversand up to $1 \mathrm{~m}$ thick overlies the older sediments.

\section{The distribution and morphology of the dunes}

Separate dunes are rare in the lowland. Most of dunes are concentrated in major dune complexes (Fig. 6.1). The later ones occupy the central and southern part of the lowland. The distribution of the inland dunes can be correlated with the area of sandy glaciolacustrine sediments; in areas with clay or silt sediments dunes are rare or absent. Significantly, the River Gauja valley represented a great obstacle for further migration of dunes to the east. Dune ridges stopped at the river valley and formed a very steep slope on the leeward side.

In total, 536 individual dune landforms were distinguished in the lowland. It is possible to distinguish 7 different dune complexes in the central and south part of the lowland. The concentration of dunes can reach up to 25 landforms per $\mathrm{km}^{2}$ in the central part of the lowland. The absolute heights of the dune bases vary from $65 \mathrm{~m}$ in the northern part up to 110 $\mathrm{m}$ a.s.l. at the Smilškalni site. The relative relief can reach up to $16.6 \mathrm{~m}$, but on average the dunes are $4.1 \mathrm{~m}$ high. Most of dunes are of compound or comb-parabolic shape, some of separate dunes being parabolic.

The azimuths of the long axes of the dunes were analysed in order to establish the main palaeowind directions. The results reveal minor variation in the wind directions between dune complexes. During the phase of dune stabilization in the Middle Gauja Lowland the main WE direction prevailed. 


\section{The internal structure of the Smilškalni dune}

A ground penetrating radar (GPR) Zond 12-e was used to determine the internal structure of the dune. GPR profiling was carried out using a common offset configuration with three antenna systems $-75 \mathrm{MHz}, 100 \mathrm{MHz}$ and $300 \mathrm{MHz}$. Data were recorded using $500 \mathrm{~ns}$ time windows, which correspond to approximately $30 \mathrm{~m}$, assuming that the real part of dielectric permittivity is 6 . The exact GPR profile length and its topography were measured at several points on the selected GPR profile line using a TopCon GRS-1 GPS/GNSS device.

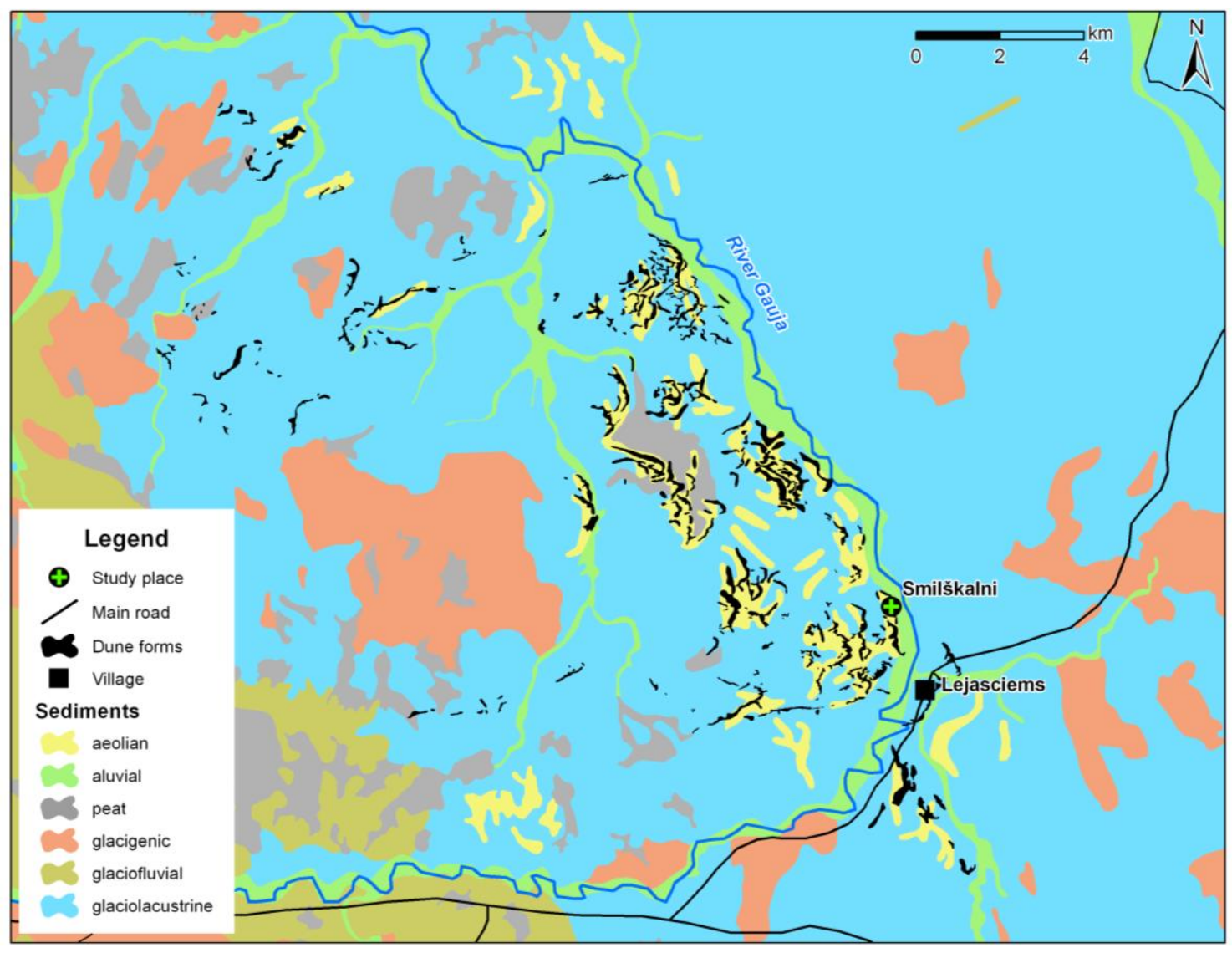

Fig. 6.1. The spatial arrangement of dunes in the central part of the lowland. Quaternary superficial deposits are shown according to Juškevičs and Skrebels (2002).

The GPR profiles were processed and analysed with Prism 2.5 software. To compensate for signal losses during propagation through the ground, the time-dependent signal gain function was used. Also, the Ormsby band-pass filter was used to extract the part of the frequency spectrum that contains informative signals. Simultaneously, the background removal filter was used to delete horizontal uninformative signals. To compensate for the time dilation arising from the fact that the transmitter and receiver antennas were separated by some distance during GPR profiling, a moveout correction was applied (Neal 2004). As the last step in GPR profile processing topographic correction was applied using the obtained GPS measurements.

During research GPR profiles of high quality were obtained. In contrast to the profiles based on the 100 and $300 \mathrm{MHz}$ antennas, the $75 \mathrm{MHz}$ antenna GPR profile revealed more subsurface information. Thus, detailed analysis was carried out on the GPR profile obtained with the $75 \mathrm{MHz}$ antenna system.

Several informative signals were identified (Fig. 6.2). The first signal (indicated by arrow No. 1 in Fig. 6.2) relates to the boundary between sediment layers with significant differences in 
electromagnetic properties. Additionally, it was possible to identify signals related to crossbedding on the lee side of the dune (No. 2 in Fig. 6.2) and a signal reflected from the groundwater level (No. 3 in Fig. 6.2). The fourth and fifth signals (No. 4 and 5 in Fig. 6.2) were reflected from the above surface objects and are considered uninformative signals.

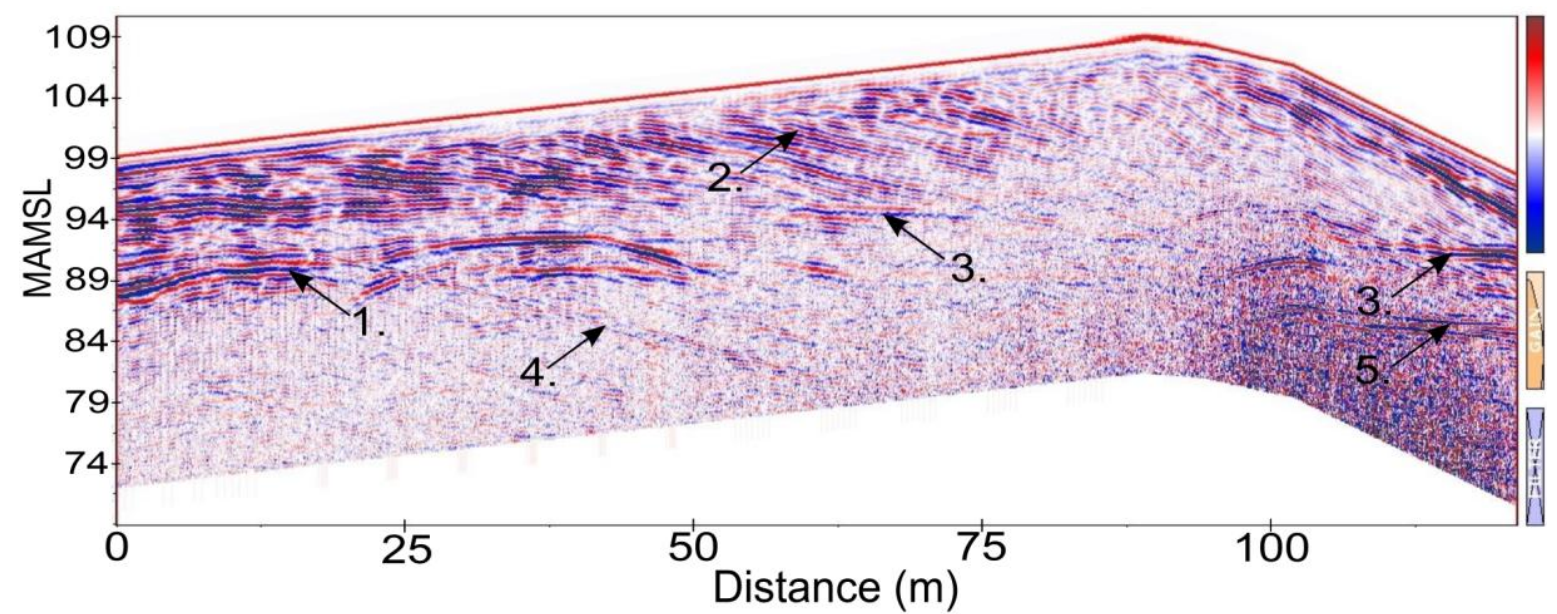

Fig. 6.2. The GPR profile of Smilškalni dune.

The dip and azimuth of dune cross-beddings were measured at 20 places in the outcrop of the Smilškalni site. Most of the dune cross-beddings dip at $14^{\circ}$ to $30^{\circ}$, indicating the lee side of the dune, and active dune migration before stabilization. These results were also in quite good agreement with observations of the dune long axis. In the lowermost part of the dune the dip of the sand beds is subhorizontal, with an angle of $3^{\circ}$ to $4^{\circ}$.

\section{The textural features of aeolian sediments of the Smilškalni dune}

The shape and surface features of quartz grains (Shrivastava et al. 2012; Vos et al. 2014) together with the grain size parameters (Vandenberghe 2013; Zhu et al. 2014) can serve as a powerful tool in deciphering the depositional environment and mode of transportation of sediments as well as their origin and classification. A multidisciplinary set of methods was applied to the Smilškalni site: (1) grain-size distribution of sediments, (2) rounding of the quartz grains and character of the quartz grain surface in the sandy fractions $(0.5-0.8,0.8-1.0$ $\mathrm{mm}$ and $>1.0 \mathrm{~mm}$ ), (3) mineral-petrographic composition in the sandy fractions. A total of two sediment sequences - upper and lower Smilškalni - were investigated.

Grain-size analysis was performed by sieving, using sieve sizes $4.0 ; 2.0 ; 1.0 ; 0.8 ; 0.5$; $0.315 ; 0.25 ; 0.2 ; 0.125 ; 0.1$ and $0.063 \mathrm{~mm}$. Based on analysis of the distribution of the size composition, logarithmic Folk and Ward (1957) graphical measures were obtained. Within the sand fraction $(0.5-0.8,0.8-1.0$ and $>1.0 \mathrm{~mm})$ quartz grains were subjected to analysis of rounding and surface frosting/mattness following two independent methodologies: (1) Mycielska-Dowgiałło and Woronko (1998) with the modification proposed by Kalińska and Nartišs (2014), and (2) Velichko and Timirieva (1995).

The mean grain size $(\mathrm{Mz})$ of the dune sand samples in the Smilškalni averages $2.07 \varphi$, with a range of $1.78 \varphi$ to $2.36 \varphi$. Simultaneously a tendency to become finer is observed in the lower part of the dune, where the average $2.35 \varphi$ of the mean is observed. Similarly, a higher sorting value $(\sigma=0.57)$ is noted in the lower part of the profile. This pattern is likely to reflect the dune-parent material relationship, where enrichment in relatively coarse grains is noted due to the selective removal of grains from substratum, something observed in numerous aeolian environments (Folk 1971; Mycielska-Dowgiałło and Ludwikowska-Kędzia 2011; 
Mycielska-Dowgiałło 2007).

Along with the rounding and surface character of quartz grains, a predominance of the aeolian factor is observed, indicated both by long-duration abrasion and/or long transport distance (RM type of grains), and short-duration abrasion and/or short transportation (EM/RM type of grains) within both sequences. The total content of such grains varies between 29.06$70.68 \%$. Simultaneously, a relatively high proportion, between $8.89-24.74 \%$, of perfectly rounded matt $(\mathrm{RM})$ grains is observed in the Smilškalni lower sequence. In general, the presence of numerous well-rounded concavities with a frosted appearance is considered a diagnostic indicator of intensive aeolian transformation (Swezey 1998). However, in terms he the outline of the remaining quartz grains observed within the investigated profiles do not conform to this pattern (see below), which rather points either to inheritance from the former environments or to the chemical solution and redeposition of silica. The latter has been proven experimentally by Kuenen and Perdok (1962) as leading to the rounding of quartz grains.

Grains with an angular outline are generally considered to be absent in the aeolian environment (Vos et al. 2014). However, there is a high content between, 21.80 to $50.00 \%$, of NU/M type grains, with sharp edges and a matt surface. Abundant NU/M quartz grains, noted in the Smilškalni upper sequence, are characterised by two features: (1) their angularity, with definitely sharp edges, and (2) their specific surface character, which under the binocular microscope resembles frosting. Indeed, the seasonal freezing of fluids causes splitting-off, and an uneven, shelly surface can be created; such grains have been observed frequently within palaeosols of loess sequences (Velichko and Timirieva 1995). Furthermore, the ubiquitous (between 14.44-34.00\%) presence of C-type (cracked) quartz grains can be explained through inheritance from local glacial/glaciofluvial lithologies, these standing in close relation to the aeolian deposits.

Application of the second independent methodology, after Velichko and Timirieva (1995), to the $>1.0 \mathrm{~mm}$ quartz fraction, revealed the aeolian nature of the investigated sequences. Completely matt and 50\% matt grains in the 3rd and 4th group of roundness, in accordance with Rukhin's (1961) classification, prevail; thus, the mattness and roundness indexes are relatively high in the Smilškalni upper sequence in particular. The outline roundness of quartz grains seems to be positively correlated with the size of the grains, indicating that aeolian transformation has affected predominantly the bigger quartz grains.

Notable is the occurrence of a significant quantity of feldspars in the investigated sequences. This suggests that the major part of the sediment has not passed through several sedimentary cycles and is instead derived directly from igneous and metamorphic rocks. Furthermore, this presumably supports the idea of immaturity, mixing and dependence upon the original formations that supplied the investigated profiles.

\section{The timing of aeolian activity}

A total of four sand samples from the Smilškalni site were processed by the optically stimulated luminescence (OSL) method using a single-aliquot regenerative dose (SAR) protocol (Murray and Wintle 2000; Wintle and Murray 2006). Samples were processed at the Nordic Laboratory for Luminescence Dating. The obtained results indicate a long time span of aeolian activity - starting from $13.71 \pm 1.01 \mathrm{ka}$ up to $10.6 \pm 0.8 \mathrm{ka}$ (unpublished data).

Notably, both textural and structural features of the dune do not indicate a long hiatus with subsequent reactivation of aeolian processes. This indicates low-intensity aeolian processes lasting a few thousands of years. In spite of the longevity of aeolian processes, the absence of palaeosol levels or any organic matter in the aeolian sediments should be noted. 


\section{References}

Āboltiňš, O. 1971. Razvitije dolini reki Gauya [Development of the River Gauja valley]. Zinātne, Rīga, 105 pp. (In Russian)

Folk, R.L. 1971. Longitudinal dunes of the northwestern edge of the Simpson Desert, Northern Territory, Australia. 1. Geomorphology and grain size relationships. Sedimentology, 16(1-2), 5-54.

Folk, R.L., Ward, W.C. 1957. Brazos River Bar: A Study in the Significance of Grain Size Parameters. Journal of Sedimentary Petrology, 27, 3-26.

Juškevičs, V., Skrebels, J. 2002. Quaternary sediments. In: Āboltiņš, O., Brangulis, A.J. (eds.), Geological map of Latvia. Scale 1:200,000. Sheets 44-Alūksne, 45-Vilıka, 54-Valka. Explanatory text and maps. State Geological Survey, Rīga, pp. 9-27.

Kalińska, E., Nartišs, M. 2014. Pleistocene and Holocene aeolian sediments of different location and geological history: A new insight from rounding and frosting of quartz grains. Quaternary International, 328-329, 311-322.

Kalm, V., Raukas, A., Rattas, M., Lasberg, K., 2011. Pleistocene Glaciations in Estonia, In: Ehlers, J., Gibbard, P.L., Hughes, P.D. (eds.), Quaternary glaciations - extent and chronology. A closer look. Developments in Quaternary Science, 15. Elsevier, pp. 95-104.

Kuenen, Ph.H., Perdok, W.G. 1962. Experimental abrasion 5. Frosting and defrosting of quartz grains. Journal of Geology, 70(6), 648-658.

Murray, A.S., Wintle, A.G. 2000. Luminescence dating of quartz using an improved single-aliquot regenerativedose protocol. Radiation Measurements 32, 57-73.

Mycielska-Dowgiałło, E. Woronko, B. 1998. Analiza obtoczenia i zmatowienia powierzchni ziarn kwarcowych frakcji piaszczystej i jej wartość interpretacyjna. Przegląd Geologiczny 46, 1275-1281.

Mycielska-Dowgiałło, E. 2007. Metody badań cech teksturalnych osadów klastycznych i wartość interpretacyjna wyników, in: Mycielska-Dowgiałło, E., Rutkowski, J. (eds.), Badania Cech Teksturalnych Osadów Czwartorzędowych i Wybrane Metody Oznaczania Ich Wieku. WSWPR, pp. 95-189.

Mycielska-Dowgiałło, E., Ludwikowska-Kędzia, M. 2011. Alternative interpretations of grain-size data from Quaternary deposits. Geologos, 17, 189-203.

Nartišs, M., Zelčs, V. 2011. A succession of Lateglacial ice-dammed lakes in north Vidzeme, Latvia. In: Johansson, P., Lunkka, J.-P., Sarala, P. (eds.), Late Pleistocene Glacigenic Deposits from the Central Part of the Scandinavian Ice Sheet to Younger Dryas End Moraine Zone. Excursion Guide and Abstracts of the INQUA Peribaltic Working Group Meeting and Excursion in Finland, 12-17 June 2011. Geological Survey of Finland, Rovaniemi, p. 122.

Neal, A. 2004. Ground-penetrating radar and its use in sedimentology: principles, problems and progress. EarthScience Reviews, 66, 261-330.

Rukhin, L.B. 1961. Principles in lithology. Gostoptekhizdat, Leningrad, 779 pp.

Shrivastava, P.K., Asthana, R., Roy, S.K., Swain, A.K., Dharwadkar, A. 2012. Provenance and depositional environment of epi-shelf lake sediment from Schirmacher Oasis, East Antarctica, vis-à-vis scanning electron microscopy of quartz grain, size distribution and chemical parameters. Polar Science, 6, 165182.

Swezey, C.S. 1998. The identification of eolian sands and sandstones. Comptes Rendus de l'Academie des Sciences - Series IIA - Earth and Planetary Science, 327(8), 513-518.

Vandenberghe, J. 2013. Grain size of fine-grained windblown sediment: A powerful proxy for process identification. Earth-Science Reviews, 121, 18-30.

Velichko, A.A., Timirieva, S.N. 1995. Morphoscopy and morphometry of quartz grains from loess and buried soil layers. GeoJournal, 36, 143-149.

Vos, K., Vandenberghe, N., Elsen, J. 2014. Surface textural analysis of quartz grains by scanning electron microscopy (SEM): From sample preparation to environmental interpretation. Earth-Science Reviews, $128,93-104$.

Wintle, A.G., Murray, A.S. 2006. A review of quartz optically stimulated luminescence characteristics and their relevance in single-aliquot regeneration dating protocols. Radiation Measurements, 41(4), 369-391.

Zelčs, V., Markots, A. 2004. Deglaciation history of Latvia. In: Ehlers, J., Gibbard, P. L. (eds.), Quaternary Glaciations - Extent and Chronology. Part I: Europe. Developments in Quaternary Science, 2. Elsevier, Amsterdam, pp. 225-243.

Zelčs, V., Markots, A., Nartišs, M., Saks, T. 2011. Chapter 18: Pleistocene Glaciations in Latvia. In: Ehlers, J., Gibbard, P.L., Hughes, P.D. (eds.), Quaternary glaciations - extent and chronology. A closer look. Developments in Quaternary Science, 15. Elsevier, pp. 221-229.

Zhu, B.Q., Yu, J.J., Rioual, P., Ren, X.Z. 2014. Particle size variation of aeolian dune deposits in the lower reaches of the Heihe River basin, China. Sedimentary Geology, 301, 54-69. 

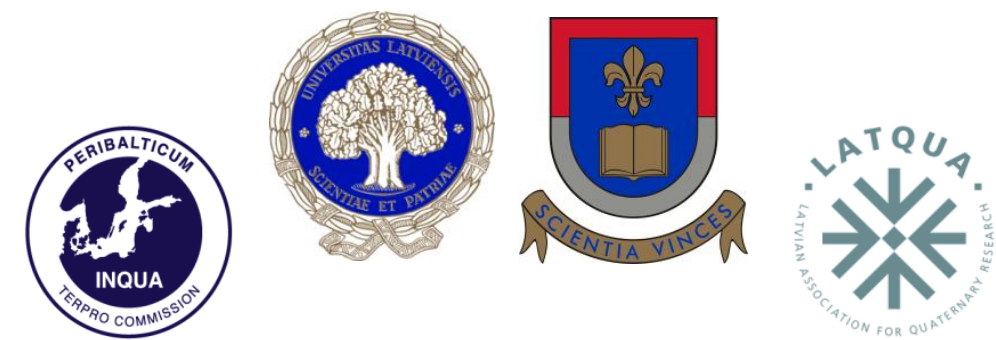

INQUA TERPRO COMMISSION PERIBALTIC WORKING GROUP

UNIVERSITY OF LATVIA

UNIVERSITY OF DAUGAVPILS

LATVIAN ASSOCIATION FOR QUATERNARY RESEARCH

\section{LATE QUATERNARY \\ TERRESTRIAL PROCESSES, SEDIMENTS AND HISTORY: FROM GLACIAL TO POSTGLACIAL ENVIRONMENTS}

EASTERN AND CENTRAL LATVIA

AUGUST 17-22, 2014 


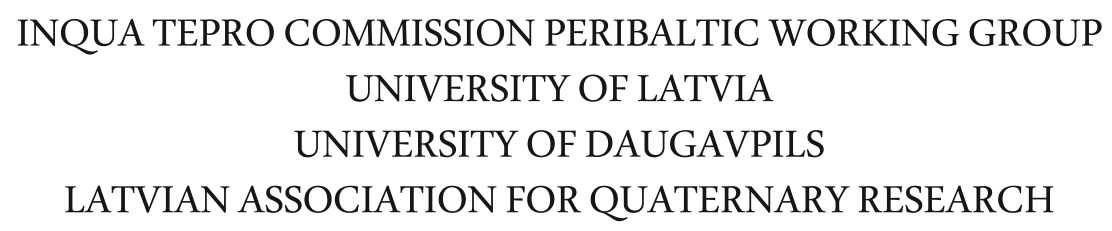

\title{
LATE QUATERNARY \\ TERRESTRIAL PROCESSES, SEDIMENTS AND HISTORY: FROM GLACIAL TO POSTGLACIAL ENVIRONMENTS
}

\author{
EASTERN AND CENTRAL LATVIA
}

AUGUST 16-22, 2014 
Organized by:

University of Latvia

Daugavpils University

Latvian Association for Quaternary Research

INQUA Peribaltic Working Group (INQUA TERPRO Commission)

Organizing committee:

Māris Nartišs (Chair, University of Latvia)

Māris Krievāns (Secretary, University of Latvia)

Aivars Markots (University of Latvia)

Juris Soms (Daugavpils University)

Evija Tērauda (University of Latvia)

Vitālijs Zelčs (University of Latvia)

Contributors:

Ivars Celiņš, Edgars Greiškalns, Ieva Grudzinska, Edyta Kalińska-Nartiša, Laimdota Kalniņa, Jānis Karušs, Māris Krievāns, Kristaps Lamsters, Aivars Markots, Māris Nartišs, Agnis Rečs, Normunds Stivriņš, Juris Soms, Ivars Strautnieks, Santa Strode, Sandra Zeimule, Vitālijs Zelčs

Editors: Vitālijs Zelčs and Māris Nartišs

The English texts of the field guide were revised by Valdis Bērziņš

Recommended reference for this publication:

Zelčs, V. and Nartišs, M. (eds.) 2014. Late Quaternary terrestrial processes, sediments and history: from glacial to postglacial environments. Excursion guide and abstracts of the INQUA Peribaltic Working Group Meeting and field excursion in Eastern and Central Latvia, August 17-22, 2014. University of Latvia, Rīga, 2014, 150 pages.

Sponsored by:

University of Latvia

Layout: Vitālijs Zelčs, Māris Nartišs and Māris Krievāns

ISBN 078-9934-517-60-0

(C) University of Latvia, 2014

This volume is available from:

Faculty of Geography and Earth Sciences

University of Latvia

Rainis Blvd. 19

Rìga, LV1586

Latvia 